\title{
Оптические и структурные свойства образцов Cd0.3Hg0.7 Te, выращенных различными методами
}

\author{
Д.А. Андрющенко ${ }^{1}$, М.С. Ружевич ${ }^{1}$, А.М. Смирнов ${ }^{1}$, К.Д. Мынбаев ${ }^{1,2}$, Н.Л. Баженов ${ }^{2}$, В.Г. Ремесник ${ }^{3}$ \\ ${ }^{1}$ Университет ИТМО, Санкт-Петербург, 197101, Кронверкский 49 \\ ${ }^{2}$ ФТИ им. А.Ф. Иоффе, Санкт-Петербург, 194021, Политехническая 26 \\ ${ }^{3}$ ИФП им. А.В. Ржанова СО РАН, Новосибирск, 630090, ак. Лаврентьева 13 \\ тел:+7 (812) 292-7182, факс:+7 (812)247-1017, эл.nочта: mynkad@mail.ioffe.ru
}

DOI 10.34077/RCSP2021-101

Твердые растворы $\mathrm{Cd}_{\mathrm{x}} \mathrm{Hg}_{1-\mathrm{x}} \mathrm{Te}$ (КРТ) являются важным материалом для изготовления фотоприемников, работающих в инфракрасной (ИК) области спектра. В настоящее время растет интерес к КРТ с $x \approx 0.3$ как материалу для приборов средневолнового ( $\lambda=2-6$ мкм) ИК диапазона [1-3]. В этом спектральном диапазоне лежат линии поглощения, обусловленного вращательными и колебательными резонансами молекул многих газов и жидкостей, включая углеводороды, что важно для приложений в области контроля окружающей среды, систем безопасности, энергоаудита, медицины, сельского хозяйства, и т.п.

Наиболее распространенные в настоящее время методы синтеза КРТ включают молекулярнолучевую эпитаксию (МЛЭ) [4], газофазную эпитаксию с использованием металлорганических соединений (МОГФЭ) [3], и, в меньшей степени, жидкофазную эпитаксию (ЖФЭ). Для материала, выращенного конкретным методом, характерна определенная дефектная структура, которая может существенно повлиять на параметры конечных устройств. В докладе будут представлены результаты сравнительного исследования оптических и структурных свойств образцов КРТ с $x \approx 0.3$, выращенных различными методами, с целью анализа перспектив использования этих материалов в различных видах приборных структур.

Оптические свойства материала исследовались методами оптического пропускания (ОП) и фотолюминесценции (ФЛ), структурные свойства - методом рентгеновской дифракции. Спектры ОП записывались при температуре 300 К с использованием спектрометров InfraLum-801 и ФСM2203. Спектры ФЛ регистрировались в интервале температур $4.2-300$ К с использованием решеточного монохроматора МДР-23. Сигнал ФЛ возбуждался полупроводниковым лазером с длиной волны 1.03 мкм и регистрировался фотоприемниками $\mathrm{InSb}$ или $\mathrm{HgCdTe}$. Для рентгеноструктурных исследований использовался дифрактометр ДРОН-8 в щелевой конфигурации с тонкофокусной рентгеновской трубкой с медным анодом и сцинтилляционным детектором $\mathrm{NaI}(\mathrm{Tl})$.

При исследовании ОП было установлено, что наиболее резкий край пропускания был характерен для образцов объемных кристаллов КРТ; наклон кривых ОП в области межзонного поглощения для всех эпитаксиальных слоев был близким. Вид и полуширина (от $\sim 13$ до 20 мэВ при $85 \mathrm{~K}$ ) спектров ФЛ всех исследованных образцов были схожими. Температурные зависимости положения максимума пика люминесценции указывали на разупорядочение твердого раствора; это проявлялось в существенном отклонении энергии пика при низких температурах от расчетного значения ширины запрещенной зоны материала. Разупорядочение наиболее сильно проявлялось в образцах, выращенных методом МЛЭ. При сопоставлении этих данных с данными рентгеновской дифракции было установлено, однако, что масштаб данного разупорядочения не был напрямую связан со структурным качеством материала, поэтому точная природа разупорядочения (стохастические и технологические флуктуации состава, и т.п.) и влияние на свойства, отличные от оптических (транспортные, и т.п.) требуют дальнейших исследований.

\section{Лumepamypa}

[1] F.Y. Yue, S.Y. Ma, J. Hong, , P.X. Yang, C.B. Jing, Y. Chen, J.H. Chu // Chin. Phys. B. 2019. T. 28. C. 017104.

[2] X.F. Qiu, S.X. Zhang, J. Zhang, Y.C. Zhu, C. Dou, S.C. Han, Y. Wu, P.P. Chen // Crystals. 2021. T. 11. C. 296.

[3] M. Kopytko, J. Sobieski, W. Gawron, A. Kebłowski, J. Piotrowski // Semicond. Sci. Technol. 2021. T. 36. C. 055003.

[4] Ю.Г. Сидоров, В.С. Варавин, С.А. Дворецкий, Н.Н. Михайлов, М.В. Якушев, И.В. Сабинина // ФТП. 2001. Т. 35. С. 1092. 